\title{
IMPACT OF ON-LINE LEARNING SYSTEM ON HIGHER EDUCATION
}

\author{
${ }^{1}$ Siva Sunasundram, ${ }^{2}$ Syed Mohammad Jamal Zaidi, ${ }^{3}$ Nurul Asyira Roslin \\ 1,2,3 Spectrum International College of Technology, Malaysia
}

\begin{abstract}
The higher education system uses traditional teaching methods in teaching and learning. The emergence of technology encompasses a great challenge for learners, teachers, and the higher education system to attain success in the learning process via the internet. Technology has made numerous changes in the process of teaching and learning. The students and teachers adopted the advent of technology in the progress of learning and teaching respectively. The pandemic situation also necessitated the adoption of the online-based learning system. The higher education system instantly instigated the online learning system into the real-time scenario. The online learning system gave numerous advantages for both the learners and teachers. Though, they faced several challenges in the process of incorporating the new system of teaching and learning. In this paper, the numerous studies and approaches of online learning systems by various researchers are discussed. Mobile-based learning, online learning in the pandemic system, and the challenges of online learning systems are addressed in this paper.
\end{abstract}

Keywords: Higher education, learning portals, digital literacy, online learning, and teaching system.

\section{Introduction}

The higher education and learning system has undergone a huge renovation in the current situation both academically and economically. The quality of the teaching and learning is improvised with the assistance of emerging technology. The traditional education system followed over several decades has been identified to be fruitless in generating excellence in the outcome. The teaching system also necessitated the technology to meet the needs of teaching as well as the process of learning [1].Innovation and creativity are initiated into the current system to attain the best outcome.

The noticeable quality on greatness is accomplished and focused on for all intents and purposes by acclimatizing the innovation in each period of life for an educator in instructing and understudies in figuring out how to cultivate the improvement in the accreditations of learning and showing framework [1].The rise of innovation has extended to a calamitous stage where the capacities of training are adjusting and advancing each day for the instructor and the student. The headway in innovation has modified all the fields by the coming of web 5.0 advancements in the movement of the homerooms in the nations with created stage and India.

The process of maintenance and handling the technologies of web 3.0 is complicated. The technology advancement alone does not subsidize the active information transmission amongst the students and teachers [2]. The current signs of progress in expertise should be appropriately integrated with the pedagogy and the content to amend an even conversion of the richness of generated knowledge via technology to the learner's mind [3]. This situation recognizes the mentors to explore the interaction through instructing learning for the absorption of technology. Emerging innovation has continually been at the vanguard of the training framework among people.

Most of the students are furnished with numerous transportable technical policies at any specified duration of time, technology endures to drive the abilities of the educational to fresh stages. The educational approaches and tools have derived from to where they are profitable in the future. The significance of the technologies in the traditional classroom is manifest, which is now more than ever in the progression of excellence in the teaching and learning process. As advancements in technology, the capabilities of educators will propagate by springs and confines. The educational trainers and the technology has been considered as a significant demesne of the education system where the work of the technology for the improvement of the trainers and the implementation of refinement as well as the innovation in the emerging technology [1].

The instruction in the twenty-first-century homerooms is equipped by the permission to the reactant 
change of innovation in the movement that has been spurred by the capacity of the educators that continues to outfit with the innovation in exercise [5]. Instructing even in the conventional school rooms has animated into a joined model where supremacy has been consented to innovation or an assortment of contraptions. An onlinebased learning framework plays out the capacity of improving understudies' satisfaction as it is dominating by using the computerized applied sciences to get admission to the scholastic educational program patio of an overall study hall.

Present work in the learning framework is intended to find out about the effect of E-Learning courseware in bettering the instructive achievement of Student Teachers seeking after B.Ed. course. The arising innovation has changed the normal approach of figuring out how to the contemporary method of the learning framework. The learning framework is incorporated through online that into the enormous term of innovation and the learning framework by means of innovation is started by the different techniques. The online-sites, video conferencing, dominating the online entries, YouTube, and versatile applications that are mixed with the learning helped apparatuses have a gigantic job in the advancement of the training framework.

Right now, the web based learning measure is improving the information on the understudies, undertaking of human capacities, specialists, and staffs associated with the scholastic by means of the web. The greater part of the colleges is fusing on the web courses in instruction for their greatness and ability improvement. In the Malaysian instruction framework, the public authority is conferring various assets to the advanced education framework [5].Based on the obtained reports from the reports, the colleges, universities; polytechnics of Malaysia have used the huge open online courses (MOOCs).

The boom of the online-based learning system in higher education in the real scenario is predicated 16.4 percent yearly over the estimated period of 2016 to 2023. With the large boom of the internet, possibly higher education and teaching frameworks will be modified in the ten to fifteen years. Thus, the education system primarily relies on the students at the higher education level by the incorporation of an online learning portal. The higher education system emphasizes the comparison of indulgence of learning among the female and male persons on the portals with online learning systems for utilization of learning in the period of COVID-19 [6].

This paper is composed of four sections. Section 2 elaborately discusses the previous reviews of the online learning system, Section 3 briefs the mobile-based learning system and online learning model, Section 4 gives the challenges of the online-based learning system and Section 5 concludes the online learning system

\section{Background Study}

In this section, various studies and learning models that are discussed as well as developed by different researchers at a different time is discussed.

\subsection{Online-Learning System}

An online learning system is a web-based communiqué stage that permits apprentices, without restrictions on time and place, to admittance in dissimilar learning tools, namely assessments, discussion boards, sharing systems for documents, and repositories of content. The traditional teaching approaches are no lengthier capable to gratify the burdens for incessant employee re-skilling and progression. Online learning systems brand learning highly available since, not only can personalities learn when it is expedient for the learner, but they similarly have admittance to training and sustenance impossibly round-the-clock.

The possibility to deliver an involvement more comparable to a classroom, with specialist straining the learners situated somewhere in the ecosphere. Online learning is rapidly becoming a vibrant portion of the teaching and learning development because it brands communiqué amongst and between the students whereas the teachers are more proficient. It also assists the organization to proliferate the environmental influence of their resources utilized in training and providing complement in the head-on teaching events[7-9].

\subsection{Online learning System and its performance}

One of the foremost expansions in the higher education organization is the utilization in the previous era that has been the acceptance of online learning system that aid the training of students. A significant feature of the online learning system is to improve the student to access the knowledge that is frequently dispersed through a higher educational institution. Since 
it is related to students in the role of educational performance. Assumed that one of the chief parts of online learning is to associate and allocate the work based on the knowledge. It is possible that online learning utilizes and is connected with performance.

Another help of internet learning is connected to customary preparing is that online learning can give adverse learning style by delivering manifold ways of the learning framework. Since advanced education establishments that help the student predilections with their online learning policies, which are probably going to improve the fulfilment of understudies with internet learning just as improve their learning, it is likely that online learning is used and it is related to enhanced performance [10-13].

\subsection{Acceptance of online learning System}

The brought together hypothesis of acknowledgment and utilization of innovation (UTAUT) assimilates and works from models to be specific the innovation acknowledgment model (TAM) and hypothesis of arranged conduct (TPB). UTAUT suggests that exertion hope (EE) impacts the student's recognition of aptitude. The apparent usability (PEOU) suits fewer significant over a period as understudies to engross with the emerging innovation for a constant epoch of period. In this manner, PEOU is foreseen to be conspicuous just in the initial phases of devouring IT. UTAUT likewise endeavoured to explain what distinct alterations can mean for IT use by suggesting that the associations among PEOU, IT, and saw convenience (PU) use can be weakened by age, gender, experience, and wilfulness of utilization [14-17].

\subsection{Digital Literacy}

Having confirmation isn't adequate to affirm that innovation will permit personalities to attain and sought after the objectives. Since definite initial abilities are needed for IT to be amazingly used. These digital proficiencies encompass the confidence and critical utilization of IS (information systems), which includes: a capability to contribute in the application environment of social networking and co-operative atmospheres, the responsiveness of security risks and threats, and also a capability to utilize the IS for inventive and creative resolutions, regardless of the framework (business, social, etc.).
Moreover the awareness of technology, digital literacy comprises the skills with cognitive and social values that are essential in the digital atmosphere. Digital literacy outline postulates five skills: reproduction skills, photo-visual skills, information skills,socio-emotional skills, and branching skills. The five skills permit individuals to direct and discover the trained web-based evidence, which is to blend, comprehend and examine it to generate a unique part of work. The set of skills specify that digital literacy is simply incisive for and distinguishing diverse forms of depiction[18-20].

\section{On-Line Learning System}

The online learning system has made several alterations in the teaching and learning process. The online-based higher education system is attained successfully by the electronic gadgets that support the internet facility. In this section, the mobile-based learning process and DM approach is discussed. Numerous researches on mobile learning has

been carried out to apprehend the utilization of mobile devices in academic settings. Certainly, mobile devices are turning ubiquitous.

This chance recommends that the utilization of mobile learning would

be precious for each learner and teacher.

Mobile Learning signifies learning concerning the utilization of mobile technology [21]. It has numerous blessings and assistance. First, this educating approach can happen at anytime, anyplace, and somewhere whereby the learning method is no longer constrained to one specific place [22]. Besides, it lets the instructors customize the guidance and enable college students to self-regulate the process of learning.

Normally, mobile learning supports college students to advance conversational skills, technological skills, discover solutions to their questions, improve an experience of collaboration, permit information sharing, and as a result, it leverages their mastering outcomes. The rapid transition to Online learning went effectively and won experience that can be incorporated in the future higher education process $[23,24]$. The lesson realized from the COVID -19 will pressure an era of new laws, platforms, regulations, and options for future scenarios.

The occasions of confinement brought about by utilizing the corona virus, and to make certain continuity 
of educating process for students, mobile-based learning is an imperative academic technology aspect in the higher education. It makes it viable for college students to collaborate, learn, and share ideas. The mobile-based learning system has assisted the students during the pandemic effectively and it has made several changes in the learning process [25].

The distant based learning framework and instructive assets to ease the deficiency of learning measure: In electronic innovation, web based learning is a very much perceived and initial utilization of learning framework. In today and around the world, the online learning system is accepting mainstream consideration.
An online learning system is characterized as the exchange of learning over the web, electronic contraptions, and innovation. Essentially, all the colleges and universities have set up the internet learning gateway of their resources and the understudies. In the 21st century, the online learning generates a more important impression on a wide range of the understudy to be specific the full-time and low maintenance or distance learning understudy in the advanced education system. The D\&M model has commanded significant notice from analysts in the area of data frameworks [26]. The D\&M model assists the internet learning system. The generally speaking framework engineering of the D\&M model is talked about in Figure 1.

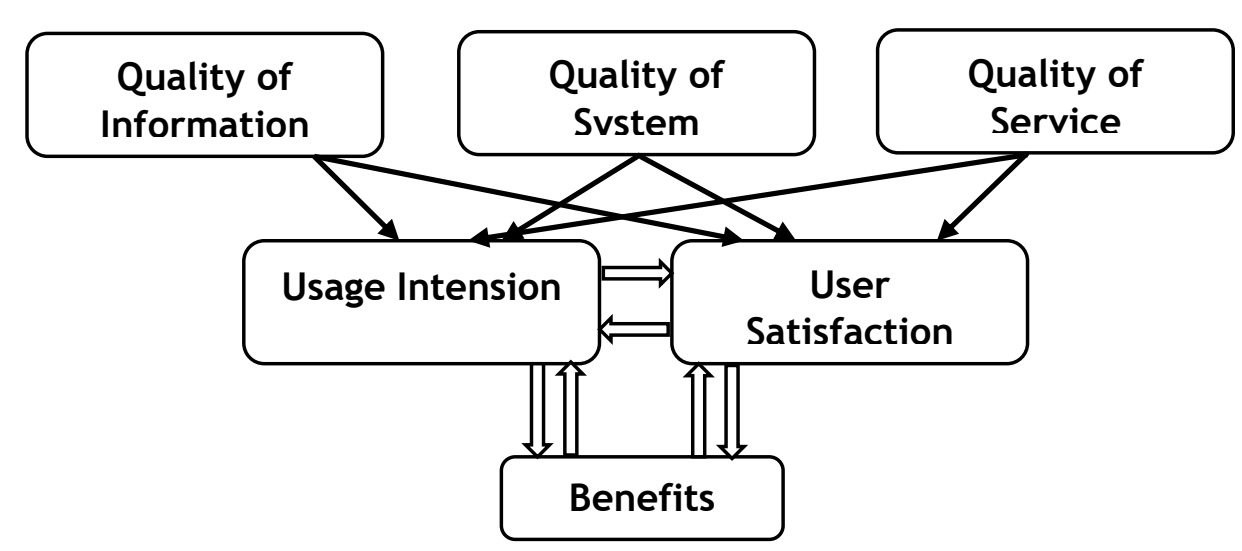

Figure 1. The DeLone and McLean IS Success Framework [27] 


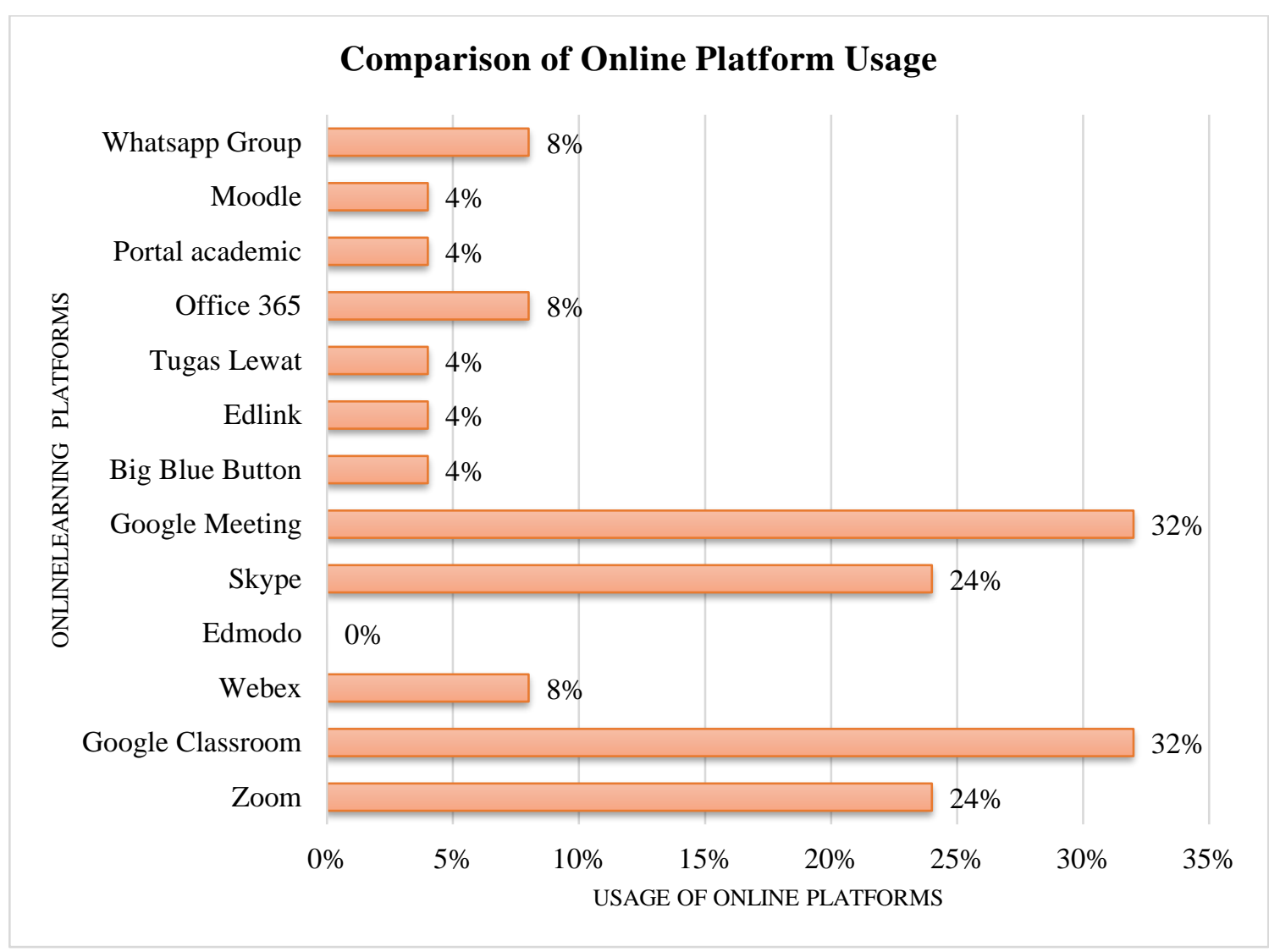

Figure 2. Comparison of Online Platform Usage

Figure 2, depicts the usage of different online platforms. The results values acquired from the online survey depict that the most utilized learning management platforms are google meeting and classroom. The video conferencing app is the second choice that is skype and zooms.

\section{Challenges of On-Line Learning System}

As online learning requires students to learn selfreliantly, they frequently identified themselves as defined by self-regulation concerns namely minimal motivation to learn and ineffectual communiqué with their associated students. In the institution of higher education where there is not a typical education system for providing online learning, students may identify them as utilizing numerous education stages for diverse courses. The pandemic derives astonishment to the lecturer who identified their way of training or common processes interrupted by the innovative way of learning.

For the lecturers who are not familiarised and skilled in generating and distributing the training materials for the online stage, this may be an important test. The higher educational organizations must confirm that they adequately sustenance the usage of online learning, not only precisely as essential by the students but also financially. In Table 1, the challenges of the online-based education system from the perspective of student, educator, and institution are discussed.

Table 1. Challenges of online learning in the perspective student, educator, and institution

\begin{tabular}{|c|c|c|}
\hline $\begin{array}{c}\text { Category of Inductive } \\
\text { Challenge }\end{array}$ & $\begin{array}{c}\text { The sub-Category of } \\
\text { Inductive Challenge }\end{array}$ & \multicolumn{1}{c|}{ Challenges } \\
\hline & $\begin{array}{c}\text { Challenges in the connectivity } \\
\text { and infrastructure }\end{array}$ & $\begin{array}{l}\text { Limited availability of data, } \\
\text { ineffective connectivity, and } \\
\text { reduced bandwidth [28]. }\end{array}$ \\
\hline
\end{tabular}




\begin{tabular}{|c|c|c|}
\hline \multirow{12}{*}{ Students } & & $\begin{array}{ll}\text { Poor infrastructure } & \text { and } \\
\text { coverage of internet [28]. } & \end{array}$ \\
\hline & \multirow{8}{*}{$\begin{array}{l}\text { Support challenges in the } \\
\text { online learning system }\end{array}$} & Presence of cognitive [29]. \\
\hline & & Accessibility [30]. \\
\hline & & $\begin{array}{l}\text { Availability help and provide } \\
\text { support technically [30]. }\end{array}$ \\
\hline & & Incidence of teaching [31]. \\
\hline & & Social incidence [31]. \\
\hline & & $\begin{array}{l}\text { Educational platform variation } \\
\text { [32] }\end{array}$ \\
\hline & & $\begin{array}{l}\text { Lack of technical device and } \\
\text { equipment [32]. }\end{array}$ \\
\hline & & Simple usage [30]. \\
\hline & \multirow{3}{*}{$\begin{array}{l}\text { Self- regulation, and } \\
\text { competency in technological } \\
\text { challenge }\end{array}$} & Minimized motivation [29]. \\
\hline & & $\begin{array}{l}\text { Efficient communication } \\
\text { establishment and maintaining } \\
\text { with the peers [33]. }\end{array}$ \\
\hline & & $\begin{array}{l}\text { Lack of knowledge on ICT } \\
\text { [28]. }\end{array}$ \\
\hline \multirow{8}{*}{ Educators } & \multirow{6}{*}{$\begin{array}{c}\text { Operational and competency } \\
\text { challenges }\end{array}$} & Huge workload [29]. \\
\hline & & Issues in the assessment [29]. \\
\hline & & $\begin{array}{l}\text { The complication in observing } \\
\text { the status of the students [29]. }\end{array}$ \\
\hline & & $\begin{array}{l}\text { Maintaining the involvement } \\
\text { and engagement of online } \\
\text { learners is challenging [34]. }\end{array}$ \\
\hline & & $\begin{array}{l}\text { Lack of formal and proper } \\
\text { training [34]. }\end{array}$ \\
\hline & & $\begin{array}{l}\text { Lessons are concentrated more } \\
\text { on the volume of data [29]. }\end{array}$ \\
\hline & & Minimized motivation [29]. \\
\hline & & Difficulties in learning [29] \\
\hline
\end{tabular}




\begin{tabular}{|c|c|c|}
\hline & $\begin{array}{l}\text { Challenges of educators self- } \\
\text { regulation }\end{array}$ & $\begin{array}{l}\text { Lack of the skill of time } \\
\text { management [29]. }\end{array}$ \\
\hline & \multirow[t]{2}{*}{$\begin{array}{c}\text { Challenges of educators } \\
\text { isolation }\end{array}$} & $\begin{array}{l}\text { Loneliness feeling in the online } \\
\text { classes [29]. }\end{array}$ \\
\hline & & $\begin{array}{l}\text { Balancing the work from home } \\
\text { and work life [34]. }\end{array}$ \\
\hline \multirow{5}{*}{ Educational Institution } & \multirow[t]{3}{*}{$\begin{array}{c}\text { Challenge in the management } \\
\text { of challenges }\end{array}$} & $\begin{array}{l}\text { Resistance to the alteration } \\
\text { [30]. }\end{array}$ \\
\hline & & Lack of awareness [30]. \\
\hline & & Lack of Interest [30]. \\
\hline & \multirow{2}{*}{$\begin{array}{l}\text { Challenges in the financial } \\
\text { support }\end{array}$} & Delay in the project [30]. \\
\hline & & Lack of financial support [30]. \\
\hline
\end{tabular}

\section{Conclusion}

Most students have the perception of technology, which influences the innovation of teaching. Over the remaining decade, human beings have assured this is a false impression generated with the aid of senior faculties who are in a single way or different perception of technology with the migrants than the competent younger faculty that are naïve to the technology. There is a progression in the growth of technology that assists in teaching with the learning classroom namely digital forms of books and smart boards. The utilization of these materials accessible by the teachers is enriched in the farfetched factor of view. Some educators appreciate such performs and acclimate to this way of gaining knowledge. However, a chief quantity of them acts to be in a distrust of its spread of effect over their students and is prejudiced to the traditional system of teaching. This paper addresses, the numerous approaches of the online learning system, mobile-based learning, online learning in the pandemic system, and the challenges of the online learning system.

\section{Reference}

1. Frank, M., Reich, N. \& Humphreys, K., 2003, Respecting the Human Needs of Students in the Development of Online learning, Computers \& Education, 40(1), 57-70.
2. Fisher, M., Thompson, G. S. \& Silverberg, D. A., (2004-2005), Effective Group Dynamics in Online learning: Case Study, Journal of Educational Technology, Systems, 33(3), 205222.

3. Weitl, F., Sub, C., Kammerl, R. \&Freitag, B., (2002), Presenting Complex Online learning Content on the Web: A Didactical Reference Model, Germany; 2002.

4. Ardito, C., De Marsico, M., Lanzilotti, R., et.al. (2004).Usability of Online learning tools. Proceedings of the working conference on Advanced visual interfaces. Audacity. http://audacity.sourceforge.net/.

5. Di Vaio, A., Boccia, F., Landriani, L., Palladino, R.: Artificial intelligence in the agri-food system: Rethinking sustainable business models in the COVID-19 scenario. Sustainability 12(12), $4851 \quad$ (2020a). https://doi.org/10.3390/su121 24851

6. Chopra, G., Madan, P., Jaisingh, P., Bhaskar, P.: Effectiveness of Online learning portal from students' perspective: A structural equation model (SEM) approach. Interactive Technology and Smart Education 16(2), 94-116 (2019). https ://doi.org/10.1108/ITSE-05-2018-0027 
7. Ngai, E., Poon, J., \& Chan, Y. (2007). Empirical examination of the adoption of WebCT using TAM. Computers \& Education, 48(2), 250-267.

8. Roca, J. C., \&Gagné, M. (2008). Understanding online learning continuance intention in the workplace: A self-determination theory perspective. Computers in Human Behavior, 24(4), 1585-1604.

9. Li, J. P., \& Kishore, R. (2006). How robust is the UTAUT instrument? A multigroup invariance analysis in the context of acceptance and use of online community web blog systems. Paper presented at the 2006 ACM Conference on Computer Personnel Research (SIGMIS CPR), Claremont, California, USA.

10. Ali-Hassan, H., Nevo, D., Kim, H., \&Perelgut, S. (2011). Organizational social computing and employee job performance: the knowledge access route. Proceedings of the 44th Hawaii International Conference on System Sciences (HICSS).

11. Goh, S. C., Elliott, C., \&Quon, T. K. (2012). The relationship between learning capability and organizational performance: A meta-analytic examination. The Learning Organization, 19(2), 92-108.

12. Eom, S. B., \&Arbaugh, J. (2011). Student Satisfaction and Learning Outcomes in ELearning: An Introduction to Empirical Research: Information Science Reference.

13. Ho, L. A., \&Kuo, T. H. (2010). How can one amplify the effect of online learning? An examination of high tech employees' computer attitude and flow experience. Computers in Human Behavior, 26(1), 23-31.

14. Venkatesh, V., Morris, M. G., Davis, G. B., \& Davis, F. D. (2003). User acceptance of information technology: Toward a unified view. MIS Quarterly, 425-478.

15. King, W. R., \& He, J. (2006). A meta-analysis of the technology acceptance model. Information \& Management, 43(6), 740-755.
16. Sun, P. C., Tsai, R. J., Finger, G., Chen, Y. Y., $\&$ Yeh, D. (2008). What drives a successful online learning? An empirical investigation of the critical factors influencing learner satisfaction. Computers \& Education, 50(4), 1183-1202.

17. Chin, W. W. (2010). How to Write Up and Report PLS Analyses. In V. Esposito Vinzi et al.(eds.) Handbook of Partial Least Squares (pp. 655-688), Springer Handbooks of Computational Statistics. Berlin Heidelberg: Springer-Verlag.

18. Buckingham, D. (2010). Defining digital literacy. Medienbildung in neuenKulturräumen, 59-71.

19. Huerta, E., \& Sandoval-Almazán, R. (2007). Digital literacy: Problems faced by telecenter users in Mexico. Information Technology for Development, 13(3), 217-232.

20. Greene, J. A., Yu, S. B., \& Copeland, D. Z. (2014). Measuring critical components of digital literacy and their relationships with learning. Computers \& Education, 76, 55-69.

21. Al-Emran, M., Elsherif, H. M., \&Shaalan, K. J. C. i. H. b. (2016). Investigating attitudes towards the use of mobile learning in higher education. Computers in Human Behavior, 56, 93-102. https://doi.org/10.1016/j.chb.2015.11.033

22. Crompton, H., Burke, D. J. C., \& Education. (2018). The use of mobile learning in higher education: A systematic review. Computers \& Education, 123, 53-64. https://doi.org/10.1016/j.compedu.2018.04.007

23. Sönmez, A., Göçmez, L., Uygun, D., \&Ataizi, M. (2018). A review of current studies of mobile learning. Journal of Educational Technology and Online Learning, 1(1), 12-27. https://doi.org/10.31681/jetol.378241

24. Basilaia, G., \&Kvavadze, D. (2020). Transition to Online Education in Schools during a SARSCoV-2 Coronavirus (COVID-19) Pandemic in Georgia. Pedagogical Research, 5(4), em0060. https://doi.org/10.29333/pr/7937 
25. Sha, L., Looi, C. K., Chen, W., \& Zhang, B. H. J. J. o. C. A. L. (2012). Understanding mobile learning from the perspective of self-regulated learning. Journal of Computer Assisted Learning, 28(4), 366-378. https://doi.org/10.1111/j.1365-

2729.2011.00461.x

26. DeLone, W.H., McLean, E.R.: Information systems success: The quest for the dependent variable. Information Systems Research 3(1), 60-95 (1992)

27. Delone, W.H., McLean, E.R.: The DeLone and McLean model of information systems success: A ten-year update. Journal of Management Information Systems 19(4), 9-30 (2003). https ://doi.org/10.1080/07421 222.2003.11045 748

28. Wan Hassan, W. A. S., Ariffin, A., Ahmad, F., Sharberi, S. N. M., Nor Azizi, M. I., and Zulkiflee, S. N. 2020. "Covid-19 Pandemic: Langkawi Vocational College Student Challenge in Using Google Classroom for Teaching and Learning (T\&amp;L)," International

29. Rannastu-Avalos, M., and Siiman, L. A. 2020. "Challenges for Distance Learning and Online Collaboration in the Time of Covid-19: Interviews with Science Teachers," Lecture Notes in Computer Science (Including Subseries Lecture Notes in Artificial Intelligence and Lecture Notes in Bioinformatics), pp. 128-142. (https://doi.org/10.1007/978-3-030-58157-2_9).

30. Almaiah, M. A., Al-Khasawneh, A., and Althunibat, A. 2020. "Exploring the Critical Challenges and Factors Influencing the Online learning System Usage during COVID-19 Pandemic," Education and Information Technologies, Springer.

31. Zulkefli, N. A. M., Hashim, H., and Syahrin, S. 2020. "Evaluating Online learning Google Classroom Tools for Computer Science Subjects during Covid-19 Pandemic," International Journal of Advanced Trends in Computer Science and Engineering (9:4), pp. 6251-6258. (https://doi.org/10.30534/ijatcse/2020/3049420 20).
32. Al-Balas, M., Al-Balas, H. I., Jaber, H. M., Obeidat, K., Al-Balas, H., Aborajooh, E. A., AlTaher, R., and Al-Balas, B. 2020. "Distance Learning in Clinical Medical Education amid COVID-19 Pandemic in Jordan: Current Situation, Challenges, and Perspective

33. Zhang, R., Mestre, P., Serodio, C., Prada, M., and Gao, W. 2020. "Web-Based Teamwork: Distributed Software Development Course under Covid-19," in 2020 15th International Conference on Computer Science \& Education (ICCSE), pp. 45-50. (https://doi.org/10.1109/ICCSE49874.2020.920 1661).

34. Farooq, F., Rathore, F. A., and Mansoor, S. N. 2020. "Challenges of Online Medical Education in Pakistan during COVID-19 Pandemic," Journal of the College of Physicians and Surgeons Pakistan (30:1), pp. S67-S69. (https://doi.org/10.29271/jcpsp.2020.Supp1. 